\title{
Increased postoperative respiratory complications in heterotaxy congenital heart disease patients with respiratory ciliary dysfunction
}

\author{
Brandon Harden, MD, ${ }^{\mathrm{a}}$ Xin Tian, PhD, ${ }^{\mathrm{b}}$ Rachel Giese, MD, ${ }^{\mathrm{c}}$ Nader Nakhleh, DO, ${ }^{\mathrm{d}}$ Safina Kureshi, MD, ${ }^{\mathrm{d}}$ \\ Richard Francis, PhD, ${ }^{\mathrm{e}}$ Sridhar Hanumanthaiah, MS, ${ }^{\mathrm{a}}$ You Li, PhD, ${ }^{\mathrm{e}}$ Matthew Swisher, MD, ${ }^{\mathrm{c}}$ \\ Karen Kuehl, MD, MPH, ${ }^{\mathrm{a}}$ Iman Sami, MD, ${ }^{\mathrm{d}}$ Kenneth Olivier, MD, MPH, ${ }^{\mathrm{f}}$ Richard Jonas, MD, ${ }^{\mathrm{a}}$ \\ Cecilia W. Lo, $\mathrm{PhD},{ }^{\mathrm{e}}$ and Linda Leatherbury, $\mathrm{MD}^{\mathrm{a}}$
}

Objective(s): Congenital heart disease (CHD) and heterotaxy patients have increased postoperative and respiratory complications. We recently showed CHD-heterotaxy patients can have respiratory ciliary dysfunction (CD) similar to that associated with primary ciliary dyskinesia, including low nasal nitric oxide and abnormal ciliary motion. In this study, we investigated whether CHD-heterotaxy patients with CD may have worse postsurgical outcomes.

Methods: We examined postsurgical outcome in 13 heterotaxy-CHD patients with CD (25 surgeries), compared with 14 heterotaxy-CHD patients without CD (27 surgeries). Outcome data were collected for each surgery, including respiratory complications, tracheostomy, use of inhaled $\beta$-agonists or nitric oxide, length of hospital stay, days on ventilator, and death.

Results: The CD versus the no-CD CHD cohorts had similar Risk Adjustment in Congenital Heart Surgery-1 risk categories, repair track, age at surgery, and follow-up evaluation times. Respiratory complications (76\% vs $37 \% ; P=.006)$, need for tracheostomy $(16 \%$ vs $0 \% ; P=.047)$, and use of inhaled $\beta$-agonists $(64 \%$ vs $11 \% ; P=.0001)$ all were increased significantly in heterotaxy-CHD patients with $\mathrm{CD}$. No significant differences were detected in postoperative hospital stay, days on mechanical ventilation, or surgical mortality. A trend toward increased mortality for the CD group beyond the postoperative period was observed $(33 \% \mathrm{vs} 0 \%$; $P=.055)$ in patients younger than age 10 years.

Conclusions: Our findings showed that heterotaxy-CHD patients with CD may have increased risks for respiratory deficiencies. Overall, there was a trend toward increased mortality in CD patients with intermediate follow-up evaluation. Because $\beta$-agonists are known to increase ciliary beat frequency, presurgical screening for $\mathrm{CD}$ and perioperative treatment of $\mathrm{CD}$ patients with inhaled $\beta$-agonists may improve postoperative outcomes and survival. (J Thorac Cardiovasc Surg 2014;147:1291-8)

\section{Supplemental material is available online.}

\footnotetext{
From the Children's National Heart Institute, ${ }^{a}$ Department of Pediatric Pulmonology, ${ }^{\mathrm{d}}$ Children's National Medical Center, Washington, DC; Office of Biostatistics Research, ${ }^{\mathrm{b}}$ Howard Hughes Medical Institute, ${ }^{\mathrm{c}}$ National Institute of Allergy and Infectious Disease, ${ }^{\mathrm{f}}$ National Institutes of Health, Bethesda, Md; and Department of Developmental Biology, ${ }^{\mathrm{e}}$ University of Pittsburgh School of Medicine, Pittsburgh, Pa.

Supported by a National Institutes of Health grant (ZO1-HL005701 to C.W.L.), Children's National Medical Center intramural funding (RAC) 2010-2011; and Matthew Swisher and Rachel Giese were generously supported by a fellowship from Howard Hughes Medical Institute.

Disclosures: Iman Sami was previously on the physician advisory board for Gilead Sciences, Inc, and Karen Kuehl has been on the physician advisory board for Cardiocore. All other authors have nothing to disclose with regard to commercial support.

Received for publication Dec 19, 2012; revisions received April 12, 2013; accepted for publication June 14, 2013; available ahead of print July 24, 2013

Address for reprints: Brandon Harden, MD, Children's Healthcare of Atlanta/Sibley

Heart Center, 2835 Brandywine Rd, Suite 300, Atlanta, GA 30341 (E-mail: hardenb@kidsheart.com).

$0022-5223 / \$ 36.00$

Copyright (c) 2014 by The American Association for Thoracic Surgery

http://dx.doi.org/10.1016/j.jtcvs.2013.06.018
}

Heterotaxy constitutes a wide spectrum of defects involving abnormal left-right patterning of organ situs in the abdominal and thoracic cavities. The aberrant left-right asymmetry can range from milder forms involving a single organ system to more complex disease involving indeterminate patterning of multiple thoracoabdominal organs. Heterotaxy occurs in approximately 1 in 10,000 live births and is associated with $3 \%$ of cases of congenital heart disease (CHD). ${ }^{1-3}$ Despite significant advances in medical and surgical management of CHD over the past few decades, short- and long-term morbidity and mortality remain high for CHD patients with heterotaxy. ${ }^{4-6}$

One study evaluating surgical outcomes after the Fontan surgery showed a 2-fold higher postoperative mortality rate for CHD patients with heterotaxy compared with CHD patients without heterotaxy. ${ }^{7} \mathrm{We}$ previously showed in a retrospective study that 87 heterotaxy-CHD patients had more postoperative complications, higher postoperative mortality rates, and increased respiratory complications compared with 634 CHD patients without laterality defects with similar Risk Adjustment in Congenital Heart Surgery-1 


$$
\begin{aligned}
& \text { Abbreviations and Acronyms } \\
& \begin{aligned}
\mathrm{CD} & =\text { ciliary dysfunction } \\
\mathrm{CHD} & =\text { congenital heart disease } \\
\mathrm{ECMO} & =\text { extracorporeal membrane oxygenation } \\
\text { PCD } & =\text { primary ciliary dyskinesia } \\
\text { PLE } & =\text { protein-losing enteropathy } \\
\text { PVR } & =\text { pulmonary vascular resistance } \\
\text { RACHS-1 } & =\text { Risk Adjustment in Congenital Heart } \\
& \text { Surgery-1 }
\end{aligned}
\end{aligned}
$$

(RACHS-1) risk categories. ${ }^{8}$ Relevant to these findings are observations from a Dnahc 5 mutant mouse model of primary ciliary dyskinesia (PCD), which showed that PCD is associated with a $40 \%$ incidence of CHD associated with heterotaxy. This observation reflects the known requirement for motile cilia function at the embryonic node for left-right patterning, and the essential role of motile cilia function in the respiratory epithelia for airway clearance. ${ }^{9}$ Together, these findings suggest a common etiology involving ciliary dysfunction in PCD and heterotaxy, and the respiratory complications in these patients. Consistent with this, a retrospective study of 337 PCD patients showed a $6 \%$ incidence of heterotaxy, with $67 \%$ of the heterotaxy patients showing CHD. ${ }^{10}$

To further investigate whether airway cilia dysfunction may be linked with CHD associated with heterotaxy, we conducted a study of CHD-heterotaxy patients to assess the prevalence of airway ciliary dysfunction (CD). Patients were evaluated with 2 tests normally used to diagnose PCD. This included measurement of nasal nitric oxide, which is typically low in PCD patients, and video microscopy of nasal airway epithelia to examine possible abnormal airway cilia motility. From these studies, we determined $42 \%$ of patients with heterotaxy-CHD have CD similar to patients with PCD, including low or borderline-low nasal nitric oxide and abnormal airway ciliary motion. ${ }^{11}$ Furthermore, sequencing analysis showed these patients were enriched for mutations in 10 known PCD genes, and analysis of respiratory symptoms suggested CHD-heterotaxy patients with $\mathrm{CD}$ older than 6 years of age have more respiratory symptoms.

In this study, we prospectively examined this same heterotaxy-CHD patient cohort, evaluating surgical outcomes in the subset of patients who underwent cardiac surgery. This included 52 surgical encounters in a total of 13 heterotaxy-CHD patients with CD (25 surgeries) and 14 heterotaxy-CHD patients without CD (27 surgeries). We hypothesized that CHD-heterotaxy patients with $\mathrm{CD}$ may have a higher morbidity/mortality rate and increased postoperative complications compared with CHD-heterotaxy patients without $\mathrm{CD}$.

\section{METHODS \\ Case Selection}

This study was approved and conducted in accordance with the Children's National Medical Center Institutional Review Board. Patients with heterotaxy and CHD undergoing cardiac surgery at the Children's National Medical Center between 2005 and 2010 were enrolled prospectively in the study based on the inclusion and exclusion criteria as previously described. ${ }^{11}$ Nasal nitric oxide measurements and videomicroscopy of airway epithelia were obtained during the preoperative evaluation or just before discharge. ${ }^{11}$ Patient care team members were blinded to ciliary function status throughout study. Briefly, heterotaxy in this study was broadly defined as deviation from normal left-right asymmetry in any thoracoabdominal organ differing from situs solitus and situs inversus totalis. ${ }^{12}$ Therefore, our case cohort comprised patients with congenital heart defects associated with laterality disorders, such as pulmonary, cardiovascular, gastrointestinal, splenic, and/or hepatobiliary systems. CHD patients are considered to have abnormal cardiovascular situs if they have dextrocardia/ mesocardia, interrupted inferior vena cava, atrial-isomerism/ambiguous/ inversus, atrioventricular discordance, superior/inferior ventricles, and ventricular-arterial discordance. Phenotype can be solely cardiovascular in nature without atrial isomerism. Isolated CHD comprising a double-outlet right ventricle with no other situs defects was excluded.

\section{Outcome Data Collection}

Relevant medical history and preoperative data including age at surgical intervention, preoperative weight, and history of neonatal respiratory distress were obtained from the medical records. Detailed surgical data and postoperative outcome data were recorded from progress notes, respiratory care data sheets, surgical reports, and discharge summaries. Postoperative length of stay; surgical procedures performed, particularly single-ventricle versus biventricular surgical tracks; and their RACHS-1 risk categories were detailed for each surgical encounter. ${ }^{13}$ RACHS-1 risk categories have been shown to correlate well with in-hospital mortality and length of postoperative hospital stay, which allows for relevant comparisons between different groups undergoing surgery for CHD. ${ }^{14}$

Postoperative mortality, defined by death within 30 postoperative days or within the postoperative hospital stay, and mortality beyond the postoperative period were collected via the cardiothoracic surgical database or death certificates in electronic medical records. Extracorporeal membrane oxygenation (ECMO) support and use of inotropic and pulmonary vasodilator medications during the postoperative period were determined. Postoperative respiratory outcome measures including length of mechanical ventilation, placement of new tracheostomy, continued need for existing tracheostomy for ventilation, use of inhaled $\beta$-agonists, duration of initial postoperative chest tube, prolonged ventilatory course, and respiratory complications were gathered for each surgical encounter. Patients with existing tracheostomies preoperatively were evaluated thoroughly by the Department of Pulmonology to determine whether the tracheostomy was needed for ventilation. Respiratory complications were broadly defined to include failed extubations, respiratory failure, culture or polymerase chain reaction-positive respiratory infection, stridor, and radiographic evidence of pleural effusions, atelectasis, pneumothorax, and pulmonary edema.

A prolonged ventilatory course was defined as postoperative mechanical ventilation for longer than 10 days based on analyzing the distribution of postoperative mechanical ventilatory duration seen in our retrospective study at this institution, which represented the upper $10 \%$ of cases. ${ }^{8}$ This definition of a prolonged ventilatory course was used previously in a pediatric cardiac surgical population. ${ }^{15}$ Preoperative pulmonary vascular resistance (PVR) was obtained from cardiac catheterization reports for all patients who underwent hemodynamic evaluation before surgical intervention, with an increased PVR defined as 3 or more Woods unit $\times \mathrm{m}^{2}$. Medical records were reviewed extensively for a diagnosis or clinical suspicion of protein-losing enteropathy (PLE) including perioperative albumin levels. Length of follow-up evaluation was available for all patients and 
was defined as the time interval from the first surgical encounter for all surviving patients. Similar data were collected for both patient cohorts.

\section{Statistical Analysis}

Continuous variables were shown as medians with interquartile ranges and categoric variables were shown by frequencies and percentages. To compare the $\mathrm{CD}$ and no-CD groups, the Mann-Whitney $U$ test was used for continuous variables and the Fisher exact test was used for categoric variables. All tests were 2-tailed and $P$ values less than .05 were considered significant; no adjustments were made for multiple comparisons.

\section{RESULTS}

Postoperative outcome measures were analyzed in 13 patients with heterotaxy CHD with ciliary dysfunction (CDgroup), representing 25 surgical encounters (Table 1), and 14 patients with heterotaxy CHD with normal ciliary function (no-CD group), representing 27 surgical encounters (Table 2). The structural heart lesion and laterality defects observed in these patients are detailed in Table E1. Among the 27 patients, $11(41 \%)$ had cardiovascular situs defects only and $16(59 \%)$ had cardiovascular and other thoracoabdominal laterality defects. Specific visceral organ situs was determined from available imaging (Table E1). Insufficient visceral organ imaging to determine situs accurately was found in 7 patients $(26 \%)$. For available records, laterality abnormalities compared with normal were present in heart position $(48 \%)$, stomach $(47 \%)$, liver $(61 \%)$, spleen $(67 \%)$, and bronchial airway/lung isomerism $(100 \%)$ in the few pulmonary imaging records.

Among all study participants, levocardia was present in 14 patients $(52 \%)$, whereas abnormal cardiac position was observed in 13 patients (48\%), with dextrocardia accounting for 11 cases $(41 \%)$ and mesocardia accounting for 2 cases ( $7 \%$ ). Atrial situs solitus was seen in 14 patients $(52 \%)$, inversus in 7 patients $(26 \%)$, and ambiguous in 6 patients $(22 \%)$. Of the 6 patients with ambiguous atrial situs, left isomerism was diagnosed in 2 patients $(33 \%)$ and right isomerism was diagnosed in 4 patients $(67 \%)$. Ventricular looping was D-looped in 19 patients $(70 \%)$ and L-looped in 8 patients $(30 \%)$. Finally, the situs of the great vessels was solitus in 3 patients $(11 \%)$, dextroposed in 12 patients $(45 \%)$, levoposed in 9 patients $(33 \%)$, and indeterminate in 3 patients $(11 \%)$.

\section{Clinical and Surgical Characteristics}

Clinical and surgical characteristics of the study groups are shown in Tables 3 and 4. The patients' ages ranged from 2 days to 46 years at the time of surgery (median age, 23.5 months and 6.8 months for $\mathrm{CD}$ and no-CD cohorts, respectively). Seventeen patients $(63 \%)$ were female and 10 patients $(37 \%)$ were male. Reflective of the overall population seen at the Children's National Medical Center, 40\% were African American, 30\% were Caucasian, 19\% were Asian, and $11 \%$ were Hispanic. The CD cohort underwent 25 cardiac surgical procedures, whereas the no-CD cohort had 27 cardiac surgeries. The median number of cardiac surgical procedures was 2 (range, 1-4) with median RACHS-1 risk categories of 3.0 (range, 2-6) in the CD and no-CD groups. Overall, 19 patients $(70 \%)$ followed a single-ventricle track and 8 patients $(30 \%)$ underwent biventricular repair. Preoperative weight was higher among the $\mathrm{CD}$ group (median weight, $10.6 \mathrm{~kg}$ ) compared with the no-CD group (median weight, $7.7 \mathrm{~kg}$ ), which is reflective of the broader age range of $\mathrm{CD}$ patients undergoing cardiac procedures.

\section{Comparison of Postsurgical Outcomes}

Comparison of age at surgery, preoperative weight, race, and sex were not statistically different between the heterotaxy-CHD patients with $\mathrm{CD}$ versus those with noCD (Tables 3 and 4). The RACHS-1 risk categories and the surgical repair track were also not statistically different (Tables 3 and 4). The median postoperative hospital stay for the 25 surgical encounters of the $\mathrm{CD}$ cohort was 8 days (mean, 19.3 days) (Table 3), which was not different from the 27 surgical encounters of the no-CD cohort, which had a median postoperative stay of 8 days (mean, 15 days) $(P=.81)$. ECMO was required postsurgically for 1 patient $(4 \%)$ in the $\mathrm{CD}$ group versus 3 patients $(11 \%)$ in the no-CD group (Table 3), which was not statistically different. Preoperative hemodynamic assessment was obtained for 18 $(72 \%)$ of the $25 \mathrm{CD}$ surgical encounters and $19(70 \%)$ of the 27 no-CD surgical encounters. Increased pulmonary vascular resistance $\left(\geq 3\right.$ Woods unit $\times \mathrm{m}^{2}$ ) was found during the preoperative hemodynamic assessment for 5 patients $(28 \%)$ in the CD group and for 3 patients $(16 \%)$ in the no-CD group, with no statistical difference seen (Table 3 ). There were 2 patients $(15 \%)$ with a diagnosis of PLE in the $\mathrm{CD}$ group, both of whom died as described later, and no patients with PLE in the no-CD group (Table 4). Use of inotropic agents (milrinone, dopamine) and pulmonary vasodilator agents (inhaled nitric oxide, sildenafil, bosen$\tan )$ was similar between the 2 groups.

\section{Comparison of Morbidity and Mortality}

We conducted a follow-up analysis of surviving patients since their first surgical encounter. This encompassed 4.1 years for the $\mathrm{CD}$ cohort and 3.7 years for the no-CD cohort (Table 4). We observed no deaths in the postoperative period for the CD group and 1 death (patient 9029) in the no-CD group. Patient 9029 died 22 days after a bidirectional Glenn procedure and total anomalous pulmonary venous return repair from complications secondary to fungal sepsis while on ECMO. There were 3 deaths $(23 \%)$ in the CD group beyond the postoperative period ( $>30$ days) compared with no deaths in the no-CD group (Table 4). Patient 9006 died of complications secondary to PLE 17 months after Fontan completion. Patient 9008 had a diagnosis of PLE and died 14 months after Fontan completion of group A 
TABLE 1. Heterotaxy patients with CHD and airway ciliary dysfunction

\begin{tabular}{|c|c|c|c|c|c|}
\hline $\begin{array}{l}\text { Patient or } \\
\text { study no. }\end{array}$ & Age & $\begin{array}{c}\text { Complete cardiovascular } \\
\text { anatomy* }\end{array}$ & Procedure (RACHS-1) & Other laterality defects & nNO (nL/min) \\
\hline \multirow[t]{2}{*}{9004} & $5 \mathrm{mo}$ & $\begin{array}{l}\{\text { S,D,D }\} \text { Levocardia, unbalanced AVC, } \\
\text { DORV, D-malposed great vessels, } \\
\text { PS, LSVC to LA, RSVC to RA, } \\
\text { RV hypoplasia, right aortic arch }\end{array}$ & Bilateral bidirectional Glenn (2) & $\begin{array}{l}\text { Asplenia, liver/stomach } \\
\text { inversus }\end{array}$ & 34 (low) \\
\hline & $2.1 \mathrm{y}$ & & Fontan (3) & & \\
\hline \multirow[t]{2}{*}{$9006 \dagger$} & $8 \mathrm{mo}$ & $\begin{array}{l}\{\text { I,D }, \mathrm{D}\} \text { Dextrocardia, DORV, PA, } \\
\text { common atrium, PAPVR, atrial } \\
\text { inversus }\end{array}$ & Bidirectional Glenn (2) & Bronchial inversus & 61 (borderline) \\
\hline & $2 \mathrm{y}$ & & Fontan (3) & & \\
\hline \multirow[t]{3}{*}{$9008 \dagger$} & $23 \mathrm{mo}$ & $\begin{array}{l}\{\mathrm{S}, \mathrm{D}, \mathrm{D}\} \text { Dextrocardia, truncus } \\
\text { arteriosus, VSD, ASD, LSVC }\end{array}$ & BT shunt (3) & - & 138 (borderline) \\
\hline & $7.2 \mathrm{y}$ & & $\begin{array}{l}\text { Bilateral bidirectional Glenn, } \\
\text { pulmonary arterioplasty (2) }\end{array}$ & & \\
\hline & $9.4 \mathrm{y}$ & & Fontan (3) & & \\
\hline \multirow[t]{4}{*}{9010} & $5 \mathrm{~d}$ & $\begin{array}{l}\{\text { S,D,D }\} \text { Levocardia, DORV, PS, } \\
\text { D-malposed great vessels, VSD }\end{array}$ & $\begin{array}{l}\text { Pericardial baffle of VSD to aorta, RV } \\
\text { to pulmonary artery conduit (4) }\end{array}$ & - & 59 (borderline) \\
\hline & 4 mo & & $\begin{array}{l}\text { Modified Konno with Gortex patch } \\
\text { ventriculoseptoplasty and resection } \\
\text { of subaortic stenosis (4) }\end{array}$ & & \\
\hline & $20 \mathrm{mo}$ & & $\begin{array}{l}\text { Modified Konno with Gortex } \ddagger \text { patch } \\
\text { ventriculoseptoplasty, homograft } \\
\text { conduit change, resection of } \\
\text { subaortic stenosis, epicardial } \\
\text { pacemaker (2) }\end{array}$ & & \\
\hline & $2.3 \mathrm{y}$ & & Mitral valve replacement (3) & & \\
\hline 9011 & $11.7 \mathrm{y}$ & $\begin{array}{l}\{\text { A,D,D }\} \text { Levocardia, unbalanced } \\
\text { AVC, HLV, PA, VSD, D-malposed } \\
\text { great vessels, bilateral SVC and } \\
\text { left-sided IVC to left-sided atrium, } \\
\text { pulmonary venous return to right- } \\
\text { sided atrium, right atrial isomerism }\end{array}$ & $\begin{array}{l}\text { Excision of aneurysmal seroma, } \\
\text { aorto-LPA shunt revision (4) }\end{array}$ & Asplenia & 85 (low) \\
\hline \multirow[t]{2}{*}{9015} & $5 \mathrm{~d}$ & $\begin{array}{l}\{\text { S,D }, \text { S }\} \text { Levocardia, unbalanced } \\
\text { AVC, hypoplastic aortic arch, } \\
\text { coarctation of aorta, LSVC to LA }\end{array}$ & Norwood/Sano (6) & Midline liver & \\
\hline & $9 \mathrm{mo}$ & & Bidirectional Glenn (2) & & 2 (low) \\
\hline \multirow[t]{3}{*}{9017} & $9 \mathrm{~d}$ & $\begin{array}{l}\{\text { I,L,L }\} \text { Dextrocardia, atrial/ventricular } \\
\text { inversus, DORV, L-malposed great } \\
\text { vessels, PA, VSD, right aortic arch, } \\
\text { LSVC and LIVC to left-sided } \\
\text { morphologic right atrium }\end{array}$ & BT shunt (3) & $\begin{array}{l}\text { Bronchial inversus, } \\
\text { abdominal situs inversus }\end{array}$ & \\
\hline & $3.4 \mathrm{y}$ & & Bidirectional Glenn (2) & & (borderline) \\
\hline & $5.9 \mathrm{y}$ & & Fontan (4) & & 55 \\
\hline 9020 & $40.1 \mathrm{y}$ & $\begin{array}{l}\{\mathrm{S}, \mathrm{L}, \mathrm{L}\} \text { Dextrocardia, DORV, } \\
\text { ventricular inversion, A-V } \\
\text { discordance, bilateral SVCs, } \\
\text { subpulmonary stenosis, VSD, left } \\
\text { aortic arch }\end{array}$ & BT shunt (3) & - & 90 (low) \\
\hline \multirow[t]{2}{*}{$9023 \dagger$} & $8 \mathrm{~d}$ & $\begin{array}{l}\{\mathrm{I}, \mathrm{L}, \mathrm{L}\} \text { Dextrocardia, DORV, } \\
\text { L-malposed great vessels, VSD, } \\
\text { right aortic arch, co-arctation of } \\
\text { aorta, supracardiac total anomalous } \\
\text { pulmonary venous drainage to } \\
\text { vertical vein, bridging vein to LSVC }\end{array}$ & $\begin{array}{l}\text { Pulmonary artery banding, } \\
\text { coarctation of aorta repair, PDA } \\
\text { ligation (3) }\end{array}$ & Abdominal situs inversus & \\
\hline & $6.2 \mathrm{mo}$ & & Bidirectional Glenn, TAPVR repair (4) & & 5 (low) \\
\hline
\end{tabular}


TABLE 1. Continued

\begin{tabular}{|c|c|c|c|c|c|}
\hline $\begin{array}{l}\text { Patient or } \\
\text { study no. }\end{array}$ & Age & $\begin{array}{c}\text { Complete cardiovascular } \\
\text { anatomy* }\end{array}$ & Procedure (RACHS-1) & Other laterality defects & nNO (nL/min) \\
\hline 9026 & $17.9 \mathrm{y}$ & $\begin{array}{l}\{\mathrm{A}, \mathrm{D}, \mathrm{X}\} \text { Dextrocardia, situs } \\
\text { ambiguous, HLHS, unbalanced } \\
\text { AVC, critical aortic valve stenosis, } \\
\text { coarctation of aorta, bilateral SVCs } \\
\text { with interrupted IVC and } \\
\text { hemiazygous continuation to } \\
\text { LSVC, right aortic arch, left atrial } \\
\text { isomerism }\end{array}$ & Fontan (3) & $\begin{array}{l}\text { Left bronchial isomerism, } \\
\text { polysplenia }\end{array}$ & 162 (borderline) \\
\hline 9027 & $8.3 \mathrm{y}$ & $\begin{array}{c}\{\text { A,D }, \text { S }\} \text { Levocardia, right aortic arch, } \\
\text { TOF with PA, MAPCAs, LSVC to } \\
\text { left atrium, left atrial isomerism }\end{array}$ & $\begin{array}{l}\text { Aortic homograft takedown and } \\
\text { repair, residual VSD closure (3) }\end{array}$ & $\begin{array}{l}\text { Left bronchial isomerism, } \\
\text { polysplenia }\end{array}$ & 123 (borderline) \\
\hline 9031 & $12.7 \mathrm{y}$ & $\begin{array}{l}\{\mathrm{I}, \mathrm{L}, \mathrm{L}\} \text { Dextrocardia, atrial situs } \\
\quad \text { inversus, } \mathrm{L}-\mathrm{malposed} \text { great vessels }\end{array}$ & Rastelli conduit replacement (3) & Abdominal situs inversus & 117 (borderline) \\
\hline 9043 & $14 \mathrm{~d}$ & $\begin{array}{l}\{\text { A,L,D }\} \text { Levocardia, DORV, HLV, } \\
\text { D-malposed great vessels, PA, } \\
\text { common atrium, ambiguous atrial } \\
\text { situs, TAPVR, right atrial } \\
\text { isomerism }\end{array}$ & BT shunt (3) & Bronchial inversus, asplenia & 9 (low) \\
\hline & $6 \mathrm{mo}$ & & Bidirectional Glenn (2) & & \\
\hline
\end{tabular}

All patients had normal cilia motion by videomicroscopy. $A S D$, Atrial septal defect; $A$ - $V$, atrioventricular; $A V C$, atrioventricular canal defect; $B T$, Blalock Taussig; $D O R V$, doubleoutlet right ventricle; $H L H S$, hypoplastic left heart syndrome; $H L V$, hypoplastic left ventricle; $I V C$, inferior vena cava; $L A$, left atrium; $L I V C$, left inferior vena cava; $L P A$, left pulmonary artery; $L S V C$, left superior vena cava; $M A P C A$, multiple aortopulmonary collateral; $n N O$, nasal nitric oxide; $P A$, pulmonary atresia; $P A P V R$, partial anomalous pulmonary venous return; $P D A$, patent ductus arteriosus; $P S$, pulmonic stenosis; RA, right atrium; RACHS-1, Risk Adjustment in Congenital Heart Surgery-1; RSVC, right superior vena cava; $R V$, right ventricle; $S V C$, superior vena cava; TAPVR, total anomalous pulmonary venous return; TOF, tetralogy of Fallot; VSD, ventricular septal defect. *Van Praagh classification (1977). †Mortality. $\ddagger$ Gore Medical, Flagstaff, Ariz.

streptococcus sepsis and cardiogenic shock in a failing Fontan while on ECMO. Patient 9023 died 26 months after a bidirectional Glenn and total anomalous pulmonary venous return repair from culture-negative sepsis and complications of dilated cardiomyopathy. There was no statistical difference in postoperative mortality ( $\leq 30$ days), mortality beyond the postoperative period ( $>30$ days), or total mortality between the 2 study groups (Table 4 ). Overall, mortality for the $\mathrm{CD}$ group beyond the postoperative period showed a trend toward significance $(33 \%$ vs $0 \%$, $P=.055)$ when patients were stratified to exclude those $(n=4)$ older than 10 years of age.

\section{Comparison of Respiratory Outcomes}

The median length of postoperative mechanical ventilation for the $25 \mathrm{CD}$ surgical encounters was 1 day (mean, 11.7 days), with 5 surgical encounters $(20 \%)$ experiencing prolonged ventilatory courses (Table 5). In comparison, the median length of postoperative mechanical ventilation for the 27 no-CD surgical encounters was 1 day (mean, 4.2 days), with a smaller proportion $(7 \% ; 2$ surgical encounters) resulting in prolonged ventilatory courses (Table 5). There was no statistical difference in the median length of postoperative ventilation $(P=.69)$ or prolonged ventilatory course $(P=.24)$ between the $\mathrm{CD}$ versus no-CD groups. The median length of initial postoperative chest tube requirement showed no statistical difference between groups, with the median length being 3 days (mean, 5.8 days) for the $\mathrm{CD}$ group and 3 days (mean, 6.6 days) for the no-CD group (Table 5).

The frequency of respiratory complications, inhaled $\beta$-agonist use, and tracheostomies was compared between the 2 groups (Table 5). Respiratory complications occurred after $19(76 \%)$ cardiac surgeries in the CD cohort. In comparison, respiratory complications occurred after only 10 (37\%) cardiac interventions in the no-CD group, which is significantly less frequent $(P<.006)$ than in the $\mathrm{CD}$ group. The occurrence of respiratory complications for each surgical encounter, the associated chest tube length, and inhaled $\beta$-agonist use are shown in Tables E2 and E3. Subgroup analysis of respiratory outcomes excluding those not known to be caused by cilia dysfunction alone (pleural effusions, stridor, and pulmonary edema) continued to show significantly more respiratory complications in the $\mathrm{CD}$ cohort $(P<.022)$. Inhaled $\beta$-agonist use postoperatively was significantly more frequent $(P<.001)$ in the $\mathrm{CD}$ versus the no-CD group. This was observed in $16(64 \%) \mathrm{CD}$ surgical cases compared with $3(11 \%)$ no-CD surgical cases. Finally, the need for a new tracheostomy or the continued requirement of an existing tracheostomy for ventilation was statistically more frequent in the $\mathrm{CD}$ versus no-CD group $(P<.047)$.

\section{DISCUSSION}

Prospective evaluation of 13 heterotaxy patients with CHD and CD undergoing cardiac surgery showed increased 
TABLE 2. Heterotaxy patients with CHD without airway ciliary dysfunction

\begin{tabular}{|c|c|c|c|c|c|}
\hline $\begin{array}{l}\text { Patient or } \\
\text { study no. }\end{array}$ & Age & Complete cardiovascular anatomy* & Procedure (RACHS-1) & Other laterality defects & nNO (nL/min) \\
\hline 9005 & $4 \mathrm{~d}$ & $\begin{array}{l}\{\mathrm{S}, \mathrm{D}, \mathrm{S}\} \text { Levocardia, VSD, ASD, } \\
\text { coarctation of aorta, interrupted IVC } \\
\text { with azygous continuation to RSVC }\end{array}$ & $\begin{array}{l}\text { VSD patch closure, ASD suture } \\
\text { closure, coarctation repair (3) }\end{array}$ & Polysplenia, midline liver & 12 (low) \\
\hline \multirow[t]{2}{*}{9007} & $6 \mathrm{mo}$ & $\begin{array}{l}\text { \{A,D,L\}Levocardia, situs ambiguous, } \\
\text { DORV, unbalanced AVC, superior/ } \\
\text { inferior ventricles, L-malposed great } \\
\text { vessels, PS, bilateral SVCs, right aortic } \\
\text { arch, right atrial isomerism }\end{array}$ & Bilateral bidirectional Glenn (2) & Asplenia, midline liver & $86(\mathrm{nl})$ \\
\hline & $2.5 \mathrm{y}$ & & Fontan (3) & & \\
\hline 9013 & $6.8 \mathrm{y}$ & $\begin{array}{c}\{\mathrm{S}, \mathrm{L}, \mathrm{L}\} \text { Dextrocardia, L-malposed great } \\
\text { vessels, PA, ASD, VSD, pulmonary } \\
\text { veins to RA, RSVC and RIVC to RA }\end{array}$ & $\mathrm{RV} \rightarrow \mathrm{PA}$ conduit replacement $(3)$ & - & $115(\mathrm{nl})$ \\
\hline \multirow[t]{3}{*}{9014} & $2 \mathrm{~d}$ & $\begin{array}{l}\{\mathrm{S}, \mathrm{D}, \mathrm{X}\} \text { Dextrocardia, superior/inferior } \\
\text { ventricles, D-malposed great vessels, } \\
\text { ASD, VSD, tricuspid stenosis, PA, } \\
\text { right aortic arch }\end{array}$ & BT shunt (3) & - & \\
\hline & $4.5 \mathrm{mo}$ & & Bidirectional Glenn (2) & & \\
\hline & $2.1 \mathrm{y}$ & & Fontan, atrial septectomy (4) & & $65(\mathrm{nl})$ \\
\hline \multirow[t]{2}{*}{9021} & $6 \mathrm{mo}$ & $\begin{array}{l}\{\mathrm{S}, \mathrm{L}, \mathrm{L}\} \text { Dextrocardia, L-TGA, VSD, } \\
\text { ASD, PS }\end{array}$ & $\begin{array}{l}\text { Bidirectional Glenn, atrial septectomy, } \\
\text { tricuspid valvuloplasty (4) }\end{array}$ & - & $23(\mathrm{nl})$ \\
\hline & $2.1 \mathrm{y}$ & & Fontan (3) & & \\
\hline \multirow[t]{3}{*}{9022} & $2 \mathrm{mo}$ & $\begin{array}{l}\{\text { S,D,D }\} \text { Levocardia, DORV, VSD, ASD, } \\
\text { HLV, D-malposed great vessels, bilateral } \\
\text { SVCs, interrupted IVC with azygous } \\
\text { continuation to RSVC, LSVC to CS }\end{array}$ & PA band (3) & - & $56(\mathrm{nl})$ \\
\hline & $7 \mathrm{mo}$ & & Bilateral bidirectional Glenn (4) & & \\
\hline & $2.4 \mathrm{y}$ & & Fontan (3) & & \\
\hline 9024 & $2.1 \mathrm{y}$ & $\begin{array}{l}\{\mathrm{I}, \mathrm{L}, \mathrm{L}\} \text { Dextrocardia, unbalanced AVC, } \\
\text { DORV inverted atria, PAPVR, L-malposed } \\
\text { great vessels, interrupted IVC with azygous } \\
\text { continuation to LSVC }\end{array}$ & Fontan (3) & Abdominal situs ambiguous & $56(\mathrm{nl})$ \\
\hline \multirow[t]{3}{*}{9025} & $5 \mathrm{~d}$ & $\begin{array}{l}\{\mathrm{I}, \mathrm{D}, \mathrm{D}\} \text { Mesocardia, atrial situs inversus, } \\
\text { D-malposed great vessels, VSD, PA, } \\
\text { right aortic arch, left-sided SVC/IVC }\end{array}$ & BT shunt (3) & $\begin{array}{l}\text { Abdominal situs inversus, } \\
\text { bronchial inversus }\end{array}$ & 10 (low) \\
\hline & $4 \mathrm{mo}$ & & Bidirectional Glenn (2) & & \\
\hline & $20 \mathrm{mo}$ & & Fontan (3) & & \\
\hline $9029 \dagger$ & $5 \mathrm{mo}$ & $\begin{array}{l}\{\text { A,D,D }\} \text { Levocardia, DORV, D-malposed } \\
\text { great vessels, HRV, PS, VSD, TAPVR, } \\
\text { right aortic arch, bilateral SVCs, } \\
\text { interrupted IVC with azygous } \\
\text { continuation, right atrial isomerism }\end{array}$ & Bidirectional Glenn, TAPVR repair (3) & $\begin{array}{l}\text { Bronchial right isomerism, } \\
\text { midline liver, asplenia }\end{array}$ & 33 (low) \\
\hline 9039 & $6 \mathrm{~d}$ & $\{\mathrm{~S}, \mathrm{D}, \mathrm{D}\}$ Levocardia, D-TGA & Arterial switch (3) & - & 19 (low) \\
\hline \multirow[t]{3}{*}{9044} & $26 \mathrm{~d}$ & $\begin{array}{l}\{\text { S,D,D }\} \text { Levocardia, single ventricle, } \\
\text { DILV, MS, AS, D-malposed great } \\
\text { vessels, coarctation of aorta }\end{array}$ & Norwood, BT shunt (6) & - & 22 (low) \\
\hline & 9 mo & & $\begin{array}{l}\text { Bidirectional Glenn, patch aortoplasty } \\
\text { of neoaorta (4) }\end{array}$ & & \\
\hline & $23 \mathrm{mo}$ & & Fontan (3) & & \\
\hline 9045 & $1 \mathrm{mo}$ & $\begin{array}{l}\{\text { S,D,D }\} \text { Levocardia, DORV, PA, ASD, } \\
\text { VSD, LSVC to CS }\end{array}$ & $\begin{array}{l}\text { VSD patch closure, } \mathrm{RV} \rightarrow \mathrm{PA} \\
\text { conduit (3) }\end{array}$ & - & 33 (low) \\
\hline \multirow[t]{2}{*}{9046} & $9.3 \mathrm{y}$ & $\begin{array}{l}\{\mathrm{I}, \mathrm{D}, \mathrm{X}\} \text { Mesocardia, atrial situs inversus, } \\
\text { DORV, PA, VSD, right aortic arch, } \\
\text { bilateral SVCs }\end{array}$ & Bidirectional Glenn (2) & $\begin{array}{l}\text { Abdominal situs inversus, } \\
\text { bronchial inversus }\end{array}$ & $238(\mathrm{nl})$ \\
\hline & $10.1 \mathrm{y}$ & & Fontan (3) & & \\
\hline
\end{tabular}


TABLE 2. Continued

\begin{tabular}{|c|c|c|c|c|c|}
\hline $\begin{array}{l}\text { Patient or } \\
\text { study no. }\end{array}$ & Age & Complete cardiovascular anatomy* & Procedure (RACHS-1) & Other laterality defects & nNO (nL/min) \\
\hline \multirow[t]{3}{*}{9049} & $16 \mathrm{~d}$ & $\begin{array}{l}\{\mathrm{S}, \mathrm{D}, \mathrm{L}\} \text { Levocardia, DORV, superior/ } \\
\text { inferior ventricles, criss-cross AV } \\
\text { valves, VSD, TS }\end{array}$ & Pulmonary artery band (3) & - & 14 (low) \\
\hline & $6 \mathrm{mo}$ & & Bidirectional Glenn (2) & & \\
\hline & $20 \mathrm{mo}$ & & Fontan (3) & & \\
\hline
\end{tabular}

risks related to respiratory deficiencies compared with 14 heterotaxy-CHD patients with no CD. CHD patients with CD showed increased postoperative respiratory complications, increased use of inhaled $\beta$-agonists, and a greater need for a new tracheostomy or continued requirement of an existing tracheostomy for ventilation. We observed no difference in early postsurgical mortality between the 2 groups. However, intermediate follow-up evaluation in the postsurgical period showed a trend toward increased mortality in the CD patients.

Our study showed significantly more respiratory complications using our broad definition during the postoperative hospitalization period for the CD cohort. CD may play an important role in the development of certain respiratory complications seen in our study, including atelectasis, pneumothorax, failed extubations, respiratory failure, and respiratory infection. However, CD alone cannot explain pleural effusions, the most commonly occurring respiratory complication in our study, and needs to be studied further. Repeat analysis excluding respiratory complications not known to be caused directly by ciliary dysfunction continued to show significantly more complications in the $\mathrm{CD}$ group.

The finding of increased use of inhaled $\beta$-agonists during the postoperative period in patients with $C D$ was unexpected because the use of inhaled $\beta$-agonists generally is avoided in cardiac patients because of the proarrhythmic properties of such medications. Administration usually is reserved only for patients who have failed other medicinal and mechanical interventions for respiratory symptoms such as atelectasis and mucous impaction. These findings are particularly interesting in light of increasing evidence that inhaled $\beta$-agonists increase ciliary beat frequency. ${ }^{16-19}$ Such findings would suggest the prophylactic treatment of heterotaxy-CHD patients with $\mathrm{CD}$ with inhaled $\beta$-agonists may have the potential to improve postoperative outcomes and survival. Larger studies are needed to further investigate the observational finding of increased inhaled $\beta$-agonist use in $\mathrm{CD}$ patients and how it alters the postsurgical course because this was not examined in our prospective study.

Our study did not detect a significant increase in pulmonary vascular resistance, or in the use of inhaled nitric oxide or ECMO support. We also did not observe any difference in length of postoperative hospital stay, length of postoperative mechanical ventilation, or prolonged ventilatory courses. This contrasts with the positive findings from our previous retrospective study that showed an increased mean length of postoperative hospital stay, mechanical ventilation, ECMO support, and prolonged ventilatory course in heterotaxy patients $(n=87)$ when compared with nonheterotaxy patients $(n=634) .{ }^{8}$ When enrolling patients for this prospective study, patients were excluded if they had compounding factors that may have altered their ciliary function assessment by nasal nitric oxide and videomicroscopy. Therefore, our patient cohort may have been healthier than the patients in our retrospective study. Given the very small sample size of the present study, further analysis of a larger cohort of patients is needed to further evaluate the effect of $\mathrm{CD}$ on these outcome parameters.

TABLE 3. Characteristics by surgical encounter

\begin{tabular}{lccc}
\hline & CD $(\mathbf{n}=\mathbf{2 5})$ & No-CD $(\mathbf{n}=\mathbf{2 7})$ & $\boldsymbol{P}$ value \\
\hline Age at surgery (mo), median (IQR) & $23.5(5.6-86.5)$ & $6.8(1.9-25.2)$ & .15 \\
Preoperative weight $(\mathrm{kg})$, median (IQR) & $10.6(5.0-23.0)$ & $7.7(4.2-10.6)$ & $3(3-3)$ \\
RACHS-1 risk category, median (IQR) & $3(2-3)$ & $8.0(6-15)$ & .14 \\
Postoperative stay (d), median (IQR) & $8(6-15)$ & $3(16)$ & .82 \\
Increased PVR $\left(\geq 3\right.$ Woods unit $\left.\times \mathrm{m}^{2}\right), \mathrm{n}(\%)^{*}$ & $5(28)$ & $3(11)$ & .45 \\
ECMO, n $(\%)$ & $1(4)$ & .61 \\
\hline
\end{tabular}

$C D$, Ciliary dysfunction; $E C M O$, extracorporeal membrane oxygenation; $I Q R$, interquartile range; $P V R$, pulmonary vascular resistance; $R A C H S-1$, Risk Adjustment in Congenital Heart Surgery-1. *Seven and 8 patients had missing PVR values in the CD and no-CD groups, respectively. 
TABLE 4. Patient characteristics

\begin{tabular}{llcc}
\hline & $\begin{array}{c}\text { CD } \\
(\mathbf{n}=\mathbf{1 3})\end{array}$ & $\begin{array}{c}\text { No-CD } \\
(\mathbf{n}=\mathbf{1 4})\end{array}$ & $\begin{array}{c}\boldsymbol{P} \\
\text { value }\end{array}$ \\
\hline Repair track, n (\%) & & & $>.99$ \\
$\quad$ Biventricular & $4(31)$ & $4(29)$ & \\
$\quad$ Single ventricular & $9(69)$ & $10(71)$ & \\
Death $\leq 30 \mathrm{~d}, \mathrm{n}(\%)$ & $0(0)$ & $1(7)$ & $>.99$ \\
Death $>30 \mathrm{~d}, \mathrm{n}(\%)$ & $3(23)$ & $0(0)$ & .098 \\
Total mortality, n (\%) & $3(23)$ & $1(7)$ & .33 \\
PLE, n (\%) & $2(15)$ & $0(0)$ & .22 \\
Neonatal respiratory distress, n (\%) & $0(0)$ & $0(0)$ & $>.99$ \\
Follow-up period since first & $4.1(3.5-5.4)$ & $3.7(3.2-3.7)$ & .27 \\
$\quad$ surgery for surviving & & & \\
patients (y), median (IQR) & & & \\
\hline$C D$, Ciliary dysfunction; $I Q R$, interquartile range; $P L E$, protein-losing enteropathy.
\end{tabular}

There were several limitations to our study, including the difficulty in evaluating all of the possible confounding variables in the postoperative critical care period including practice variability among providers. There was also difficulty in the evaluation of noncardiac laterality defects because there often was insufficient imaging data available to perform a complete assessment of visceral organ laterality. Also not documented in the medical records were the reason(s) why each patient was given an inhaled $\beta$-agonist and whether clinical improvement was observed after treatment. In addition, our study was not large enough to perform a subanalysis of the CD cohort to determine if patients given $\beta$-agonists had better outcomes and fewer respiratory complications.

\section{CONCLUSIONS}

Our study showed heterotaxy-CHD patients with CD have increased risks for respiratory complications, greater need for a tracheostomy, and increased use of inhaled $\beta$-agonists. A trend toward increased mortality for the CD group beyond the postoperative period was seen in patients younger than age 10 years. Airway ciliary dysfunction indeed could be a marker of other systemic diseases, giving heterotaxy patients an inborn weakness in defending

TABLE 5. Respiratory outcome measures by surgical encounter

\begin{tabular}{lccc}
\hline & $\begin{array}{c}\text { CD } \\
(\mathbf{n}=\mathbf{2 5})\end{array}$ & $\begin{array}{c}\text { No-CD } \\
(\mathbf{n = 2 7})\end{array}$ & $\begin{array}{c}P \\
\text { value }\end{array}$ \\
\hline Mechanical ventilation (d), median (IQR) & $1(1.0-3)$ & $1(1-3)$ & .69 \\
Chest tube length (d), median (IQR) & $3(2-6)$ & $3(2-7)$ & .98 \\
Prolonged ventilatory course ( $\geq 10 \mathrm{~d})$, & $5(20)$ & $2(7)$ & .24 \\
$\quad$ n (\%) & & & \\
Respiratory complications, n (\%) & $19(76)$ & $10(37)$ & .006 \\
Total tracheostomies, n (\%)* & $4(16)$ & $0(0)$ & .047 \\
New tracheostomies, n (\%) & $2(9)$ & $0(0)$ & .21 \\
Inhaled $\beta$-agonists use, n (\%) & $16(64)$ & $3(11)$ & .001 \\
\hline
\end{tabular}

$C D$, Ciliary dysfunction; $I Q R$, interquartile range. *Includes new tracheostomies as well as existing tracheostomies required for ventilation. postoperative stresses. Larger studies are needed to further investigate respiratory complications and the emergence of respiratory symptoms and disease during long-term followup evaluation in heterotaxy-CHD patients with CD. Such studies may suggest the need for changing the standard of care for these high-risk heterotaxy-CHD patients to include preoperative screening for $\mathrm{CD}$ and instituting aggressive perioperative pulmonary therapy for those with $\mathrm{CD}$ to help improve postsurgical outcomes.

The authors thank the following for their support and knowledge in their respective fields that improved this research study: Charlie Berul, MD, Anastassios Koumbourlis, MD, Dinesh Pillai, MD, Silvia Delgado, MD, and Kathleen Cummins, NP.

\section{References}

1. Lin AE, Ticho BS, Houde K, Westgate MN, Holmes LB. Heterotaxy: associated conditions and hospital-based prevalence in newborns. Genet Med. 2000;2: 157-72.

2. Reller MD, Strickland MJ, Riehle-Colarusso T, Mahle WT, Correa A. Prevalence of congenital heart defects in metropolitan Atlanta, 1998-2005. J Pediatr. 2008; 153:807-13.

3. Zhu L, Belmont JW, Ware SM. Genetics of human heterotaxias. Eur J Hum Genet. 2006;14:17-25.

4. Bartz PJ, Driscoll DJ, Dearani JA, Puga FJ, Danielson GK, O'Leary PW, et al. Early and late results of the modified fontan operation for heterotaxy syndrome 30 years of experience in 142 patients. J Am Coll Cardiol. 2006;48:2301-5.

5. Eronen MP, Aittomaki KA, Kajantie EO, Sairanen HI, Pesonen EJ. The outcome of patients with right atrial isomerism is poor. Pediatr Cardiol. 2013; 34:302-7.

6. Lim JS, McCrindle BW, Smallhorn JF, Golding F, Caldarone CA, Taketazu M, et al. Clinical features, management, and outcome of children with fetal and postnatal diagnoses of isomerism syndromes. Circulation. 2005;112:2454-61.

7. Kim SJ, Kim WH, Lim HG, Lee JY. Outcome of 200 patients after an extracardiac Fontan procedure. J Thorac Cardiovasc Surg. 2008;136:108-16.

8. Swisher M, Jonas R, Tian X, Lee ES, Lo CW, Leatherbury L. Increased postoperative and respiratory complications in patients with congenital heart disease associated with heterotaxy. J Thorac Cardiovasc Surg. 2011;141:637-44, e1-3.

9. Tan SY, Rosenthal J, Zhao XQ, Francis RJ, Chatterjee B, Sabol SL, et al. Heterotaxy and complex structural heart defects in a mutant mouse model of primary ciliary dyskinesia. J Clin Invest. 2007;117:3742-52.

10. Kennedy MP, Omran H, Leigh MW, Dell S, Morgan L, Molina PL, et al. Congenital heart disease and other heterotaxic defects in a large cohort of patients with primary ciliary dyskinesia. Circulation. 2007;115:2814-21.

11. Nakhleh N, Francis R, Giese RA, Tian X, Li Y, Zariwala MA, et al. High prevalence of respiratory ciliary dysfunction in congenital heart disease patients with heterotaxy. Circulation. 2012;125:2232-42.

12. Brueckner M. Heterotaxia, congenital heart disease, and primary ciliary dyskinesia. Circulation. 2007;115:2793-5.

13. Jenkins KJ, Gauvreau K, Newburger JW, Spray TL, Moller JH, Iezzoni LI. Consensus-based method for risk adjustment for surgery for congenital heart disease. J Thorac Cardiovasc Surg. 2002;123:110-8.

14. Boethig D, Jenkins KJ, Hecker H, Thies WR, Breymann T. The RACHS-1 risk categories reflect mortality and length of hospital stay in a large German pediatric cardiac surgery population. Eur J Cardiothorac Surg. 2004;26:12-7.

15. Szekely A, Sapi E, Kiraly L, Szatmari A, Dinya E. Intraoperative and postoperative risk factors for prolonged mechanical ventilation after pediatric cardiac surgery. Paediatr Anaesth. 2006;16:1166-75.

16. Brueckner M. Impact of genetic diagnosis on clinical management of patients with congenital heart disease: cilia point the way. Circulation. 2012;125:2178-80.

17. Salathe M. Effects of beta-agonists on airway epithelial cells. J Allergy Clin Immunol. 2002;110(Suppl):S275-81.

18. Shiima-Kinoshita C, Min KY, Hanafusa T, Mori H, Nakahari T. Beta 2-adrenergic regulation of ciliary beat frequency in rat bronchiolar epithelium: potentiation by isosmotic cell shrinkage. J Physiol. 2004;554:403-16.

19. Wong LB, Miller IF, Yeates DB. Stimulation of ciliary beat frequency by autonomic agonists: in vivo. J Appl Physiol. 1988;65:971-81. 
TABLE E1. Cardiovascular anatomy and organ situs

\begin{tabular}{|c|c|c|c|c|c|}
\hline Cardiovascular anatomy & CD, n (\%) & No-CD, n (\%) & Organ situs & CD, n (\%) & No-CD, n (\%) \\
\hline Cardiac position & & & Stomach & & \\
\hline Dextrocardia & $7(54)$ & $4(29)$ & Normal & $5(38)$ & $4(29)$ \\
\hline Mesocardia & - & $2(14)$ & Opposite & $4(31)$ & $3(21)$ \\
\hline \multirow[t]{2}{*}{ Levocardia } & $6(46)$ & $8(57)$ & Midline & - & $1(7)$ \\
\hline & & & No record & $4(31)$ & $6(43)$ \\
\hline \multicolumn{6}{|l|}{ Venous anomalies } \\
\hline Interrupted inferior vena cava & $1(8)$ & $4(29)$ & Liver & & \\
\hline Bilateral superior vena cava & $7(54)$ & $5(36)$ & Normal & $4(31)$ & $3(21)$ \\
\hline \multirow[t]{2}{*}{ Anomalous pulmonary venous return } & $3(23)$ & $3(21)$ & Opposite & $4(31)$ & $2(14)$ \\
\hline & & & Midline & $1(8)$ & $4(29)$ \\
\hline Atria and ventricles & & & No record & $4(31)$ & $5(36)$ \\
\hline Atrioventricular discordance & $4(31)$ & $5(36)$ & & & \\
\hline Atrioventricular septal defect & $4(31)$ & $2(14)$ & Spleen & & \\
\hline Atrial septal defect & $1(8)$ & $6(43)$ & Normal & $3(23)$ & $3(21)$ \\
\hline Ventricular septal defect & $8(62)$ & $10(71)$ & Right & $3(23)$ & $2(14)$ \\
\hline Atrioventricular valve atresia/stenosis & - & $2(14)$ & Asplenia & $2(15)$ & $2(14)$ \\
\hline \multirow[t]{2}{*}{ Common atrium } & $2(15)$ & - & Polysplenia & $2(15)$ & $1(7)$ \\
\hline & & & No record & $3(23)$ & $6(43)$ \\
\hline Ventricular outflow and great vessels & & & Lungs & & \\
\hline Ventriculoarterial discordance & $10(77)$ & $11(79)$ & Normal & - & - \\
\hline Double-outlet right ventricle & $7(54)$ & $7(50)$ & Inverted & $3(23)$ & $2(14)$ \\
\hline Pulmonary stenosis/atresia & $8(62)$ & $8(57)$ & Left isomerism & $2(15)$ & - \\
\hline Truncus arteriosus & $1(8)$ & - & Right isomerism & - & $1(7)$ \\
\hline Aortic stenosis/atresia & $1(8)$ & $1(7)$ & No record & $8(62)$ & $11(79)$ \\
\hline Coarctation & $3(23)$ & $2(14)$ & & & \\
\hline Right arch & $5(38)$ & $5(36)$ & & & \\
\hline Double inlet left ventricle & - & $1(7)$ & & & \\
\hline \multicolumn{6}{|l|}{ Van Praagh classification* } \\
\hline$\{\mathrm{S}, \mathrm{D}, \mathrm{S}\}$ & $1(8)$ & $1(7)$ & & & \\
\hline$\{\mathrm{S}, \mathrm{D}, \mathrm{D}\}$ & $3(23)$ & $4(29)$ & & & \\
\hline$\{\mathrm{S}, \mathrm{L}, \mathrm{L}\}$ & $1(8)$ & $2(14)$ & & & \\
\hline$\{\mathrm{S}, \mathrm{D}, \mathrm{X}\}$ & - & $1(7)$ & & & \\
\hline$\{\mathrm{S}, \mathrm{D}, \mathrm{L}\}$ & - & $1(7)$ & & & \\
\hline$\{\mathrm{I}, \mathrm{L}, \mathrm{L}\}$ & $3(23)$ & $1(7)$ & & & \\
\hline$\{\mathrm{I}, \mathrm{D}, \mathrm{D}\}$ & $1(8)$ & $1(7)$ & & & \\
\hline$\{\mathrm{I}, \mathrm{D}, \mathrm{X}\}$ & - & $1(7)$ & & & \\
\hline$\{\mathrm{A}, \mathrm{D}, \mathrm{D}\}$ & $1(8)$ & $1(7)$ & & & \\
\hline$\{\mathrm{A}, \mathrm{D}, \mathrm{S}\}$ & $1(8)$ & - & & & \\
\hline$\{\mathrm{A}, \mathrm{D}, \mathrm{L}\}$ & - & $1(7)$ & & & \\
\hline$\{\mathrm{A}, \mathrm{D}, \mathrm{X}\}$ & $1(8)$ & - & & & \\
\hline$\{\mathrm{A}, \mathrm{L}, \mathrm{D}\}$ & $1(8)$ & - & & & \\
\hline
\end{tabular}

$C D$, Ciliary dysfunction. *Van Praagh classification (1977). 
TABLE E2. Respiratory complications in heterotaxy patients with ciliary dysfunction

\begin{tabular}{|c|c|c|c|c|c|c|c|c|c|c|c|c|}
\hline & $\begin{array}{c}\text { Surgical } \\
\text { encounter }\end{array}$ & $\begin{array}{l}\text { Chest tube } \\
\text { length (d) }\end{array}$ & $\begin{array}{c}\beta \text {-agonist } \\
\text { use }\end{array}$ & $\begin{array}{c}\text { Pleural } \\
\text { effusions }\end{array}$ & Atelectasis & Pneumothorax & $\begin{array}{c}\text { Failed } \\
\text { extubation }\end{array}$ & $\begin{array}{c}\text { Respiratory } \\
\text { failure }\end{array}$ & $\begin{array}{c}\text { Respiratory } \\
\text { infection }\end{array}$ & Stridor & $\begin{array}{c}\text { Pulmonary } \\
\text { edema }\end{array}$ & Tracheostomy \\
\hline \multirow[t]{2}{*}{9004} & $5 \mathrm{mo}$ & 2 & $\mathrm{Y}$ & & & & & & & $\mathrm{x}$ & & \\
\hline & $2.1 \mathrm{y}$ & 8 & $\mathrm{~N}$ & & & & & & & & & \\
\hline \multirow[t]{2}{*}{9006} & $8 \mathrm{mo}$ & 11 & $\mathrm{Y}$ & & & & & & & & & \\
\hline & $2 y$ & 2 & $\mathrm{Y}$ & $\mathrm{x}$ & & & & & & & & \\
\hline \multirow[t]{3}{*}{9008} & $23 \mathrm{mo}$ & 5 & $\mathrm{~N}$ & $\mathrm{x}$ & & $\mathrm{x}$ & & & & & & \\
\hline & $7.2 \mathrm{y}$ & 2 & $\mathrm{~N}$ & $\mathrm{x}$ & $\mathrm{x}$ & & & & & & & \\
\hline & $9.4 \mathrm{y}$ & 2 & $\mathrm{Y}$ & $\mathrm{x}$ & $\mathrm{x}$ & & & & & & $\mathrm{x}$ & \\
\hline \multirow[t]{4}{*}{9010} & $5 \mathrm{~d}$ & 2 & $\mathrm{Y}$ & & & & & & & & & \\
\hline & $4 \mathrm{mo}$ & 2 & $\mathrm{Y}$ & & & & & & & & & \\
\hline & $20 \mathrm{mo}$ & 2 & $\mathrm{Y}$ & & & & & & & & & \\
\hline & $2.3 \mathrm{y}$ & 3 & $\mathrm{Y}$ & & & & & & & & & \\
\hline 9011 & $11.7 \mathrm{y}$ & 6 & $\mathrm{~N}$ & $\mathrm{x}$ & $\mathrm{x}$ & & & & & & & \\
\hline \multirow[t]{2}{*}{9015} & $5 \mathrm{~d}$ & 47 & $\mathrm{Y}$ & $\mathrm{x}$ & & & $\mathrm{x}$ & $\mathrm{x}$ & & & & $\mathrm{x}$ \\
\hline & $9 \mathrm{mo}$ & 4 & $\mathrm{Y}$ & & & & & & & & & $\mathrm{x}$ \\
\hline \multirow[t]{3}{*}{9017} & $9 \mathrm{~d}$ & 1 & $\mathrm{~N}$ & & & & & & $\mathrm{x}$ & & & \\
\hline & $3.4 \mathrm{y}$ & 3 & $\mathrm{~N}$ & & & & & & & & & \\
\hline & $5.9 \mathrm{y}$ & 8 & $\mathrm{~N}$ & $\mathrm{x}$ & & & & & & & & \\
\hline 9020 & $40.1 \mathrm{y}$ & 11 & $\mathrm{Y}$ & & & $\mathrm{x}$ & & & $\mathrm{x}$ & & & \\
\hline \multirow[t]{2}{*}{9023} & $8 \mathrm{~d}$ & 5 & $\mathrm{Y}$ & $\mathrm{x}$ & $\mathrm{x}$ & $\mathrm{x}$ & & & & & & $\mathrm{x}$ \\
\hline & $6.2 \mathrm{mo}$ & 4 & $\mathrm{Y}$ & $\mathrm{x}$ & & & & & & & & $\mathrm{x}$ \\
\hline 9026 & $17.9 \mathrm{y}$ & 6 & $\mathrm{~N}$ & $\mathrm{x}$ & & & & & & & & \\
\hline 9027 & $8.3 \mathrm{y}$ & 2 & $\mathrm{Y}$ & $\mathrm{x}$ & & & & & $\mathrm{x}$ & & & \\
\hline 9031 & $12.7 \mathrm{y}$ & 2 & $\mathrm{~N}$ & & & $\mathrm{x}$ & & & & & & \\
\hline \multirow[t]{2}{*}{9043} & $14 \mathrm{~d}$ & 2 & $\mathrm{Y}$ & & $\mathrm{x}$ & & $\mathrm{x}$ & & & & & \\
\hline & $6 \mathrm{mo}$ & 2 & $\mathrm{Y}$ & & $\mathrm{x}$ & & & & & & & \\
\hline
\end{tabular}

TABLE E3. Respiratory complications in heterotaxy patients without ciliary dysfunction

\begin{tabular}{|c|c|c|c|c|c|c|c|c|c|c|c|c|}
\hline & $\begin{array}{c}\text { Surgical } \\
\text { encounter }\end{array}$ & $\begin{array}{l}\text { Chest tube } \\
\text { length (d) }\end{array}$ & $\begin{array}{c}\beta \text {-agonist } \\
\text { use }\end{array}$ & $\begin{array}{c}\text { Pleural } \\
\text { effusions }\end{array}$ & Atelectasis & Pneumothorax & $\begin{array}{c}\text { Failed } \\
\text { extubation }\end{array}$ & $\begin{array}{c}\text { Respiratory } \\
\text { failure }\end{array}$ & $\begin{array}{l}\text { Respiratory } \\
\text { infection }\end{array}$ & Stridor & $\begin{array}{c}\text { Pulmonary } \\
\text { edema }\end{array}$ & Tracheostomy \\
\hline 9005 & $4 \mathrm{~d}$ & 3 & $\mathrm{~N}$ & & $\mathrm{x}$ & & & & & & & \\
\hline \multirow[t]{2}{*}{9007} & $6 \mathrm{mo}$ & 2 & $\mathrm{~N}$ & & & & & & & & & \\
\hline & $2.5 \mathrm{y}$ & 29 & $\mathrm{~N}$ & $\mathrm{x}$ & & $\mathrm{x}$ & & & & & & \\
\hline 9013 & $6.8 \mathrm{y}$ & 2 & $\mathrm{~N}$ & & & & & & & & & \\
\hline \multirow[t]{3}{*}{9014} & $2 \mathrm{~d}$ & 4 & $\mathrm{~N}$ & & $\mathrm{x}$ & & & & & & & \\
\hline & $4.5 \mathrm{mo}$ & 2 & $\mathrm{~N}$ & & & & & & & & & \\
\hline & $2.1 \mathrm{y}$ & 7 & $\mathrm{~N}$ & $\mathrm{x}$ & & & & & & & & \\
\hline \multirow[t]{2}{*}{9021} & $6 \mathrm{mo}$ & 3 & $\mathrm{~N}$ & & & & & & & & $\mathrm{x}$ & \\
\hline & $2.1 \mathrm{y}$ & 7 & $\mathrm{~N}$ & & & & & & & & & \\
\hline \multirow[t]{3}{*}{9022} & $2 \mathrm{mo}$ & 7 & $\mathrm{~N}$ & $\mathrm{x}$ & & & & & & & & \\
\hline & $7 \mathrm{mo}$ & 2 & $\mathrm{~N}$ & $\mathrm{x}$ & & & & & & & & \\
\hline & $2.4 \mathrm{y}$ & 1 & $\mathrm{~N}$ & & $\mathrm{x}$ & & & & $\mathrm{x}$ & & & \\
\hline 9024 & $2.1 \mathrm{y}$ & 26 & $\mathrm{~N}$ & $\mathrm{x}$ & & & & & & & & \\
\hline \multirow[t]{3}{*}{9025} & $5 \mathrm{~d}$ & 2 & $\mathrm{~N}$ & & & & & & & & & \\
\hline & $4 \mathrm{mo}$ & 1 & $\mathrm{~N}$ & & & & & & & & & \\
\hline & $20 \mathrm{mo}$ & 6 & $\mathrm{~N}$ & & & & & & & & & \\
\hline 9029 & $5 \mathrm{mo}$ & 22 & Y & & & & & & $\mathrm{x}$ & & & \\
\hline 9039 & $6 \mathrm{~d}$ & 1 & $\mathrm{Y}$ & & $\mathrm{x}$ & & & & & & & \\
\hline \multirow[t]{3}{*}{9044} & $26 \mathrm{~d}$ & 19 & $\mathrm{~N}$ & & & & & & & & & \\
\hline & $9 \mathrm{mo}$ & 3 & $\mathrm{~N}$ & & & & & & & & & \\
\hline & $23 \mathrm{mo}$ & 4 & $\mathrm{~N}$ & & & & & & & & & \\
\hline 9045 & $1 \mathrm{mo}$ & 2 & Y & & & & & & & & & \\
\hline \multirow[t]{2}{*}{9046} & $9.3 \mathrm{y}$ & 2 & $\mathrm{~N}$ & & & & & & & & & \\
\hline & $10.1 \mathrm{y}$ & 14 & $\mathrm{~N}$ & & & & & & & & & \\
\hline \multirow[t]{3}{*}{9049} & $16 \mathrm{~d}$ & 1 & $\mathrm{~N}$ & & & & & & & & & \\
\hline & $6 \mathrm{mo}$ & 2 & $\mathrm{~N}$ & & & & & & & & & \\
\hline & $20 \mathrm{mo}$ & 5 & $\mathrm{~N}$ & & & & & & & & & \\
\hline
\end{tabular}

